\title{
Overview Knowledge and Attitudes of Parents in the Application of Protocol Health in Children During the Covid-19 Pandemic
}

\section{Zakiah, Suyati}

Lecturer of Diploma Midwifery, Faculty of Health Sciences

Universitas Pesantren Tinggi

Darul 'Ulum Jombang Indonesia

\section{Email:}

zakiahmusyaffa@gmail.com

Received: October $4^{\text {nd }} 2021$

Accepted : October $15^{\text {rd }} 2021$

Published : November $27^{\text {th }} 2021$

\section{ABSTRACT}

COVID-19 has been declared a global pandemic by WHO. The spread of the Corona virus can trigger anxiety for parents, especially for those who have small children. Transmission of Covid-19 in children is usually caused by weak immunity or transmission from adults. For this reason, families, especially parents, need to give the education, understanding and protect their children from Covid-19 transmission by implementing health protocols. The purpose of this research is to know the description of knowledge and attitudes of parents in the application of health protocols to children during the covid-19 pandemic.

This research is a descriptive research by using primary data obtained from questionnaires. Respondents is 30 parents which have children who study at TK Darul Falah Cukir Jombang. Data are analyzed univariate and presented in the form of tabel.

The results of the knowledge level variable data shows 26 responden $(87.5 \%)$ have a good level of knowledge, and 4 people $(12.5 \%)$ has sufficient knowledge level. The attitude variable data show that all respondents $(100 \%)$ have a positive attitude in applying health protocols to children during the covid-19 pandemic.

The conclusion is the level of knowledge and attitudes of parents in implementing health protocols for children during the COVID19 pandemic at TK Darul Falah Cukir Jombang is mostly in the good category. Parents are expected to always facilitate their children in implementing health protocols to prevent the spread of COVID-19.

Keywords: Knowledge, attitude, covid-19, health protocol

Copyright (C) 2021 IIK STRADA Indonesia All right reserved.

This is an open-acces article distributed under the terms of the Creative Commons AttributionShareAlike 4.0 International License.

\section{INTRODUCTION}

Covid-19 is a type of disease caused by a virus from the coronavirus group, namely SARSCoV-2 which is also often called the corona virus. The virus, which was the forerunner of the first pandemic in Wuhan, China in December 2019. In a short time it spread to various countries including Indonesia, so that Covid-19 had been declared a world pandemic by the World Health Organization (WHO)(CNN Indonesia, 2020).

The number of deaths due to corona on a monthly basis had shown a downward trend at the beginning of this year. The number of 7,315 people in January 2021 fell 14.7\% to 6,240 in February 
2021. Then, it fell again to 4,850 people in March 2021 and 4,515 people in April 2021. However, the trend reversed the following months. The number of deaths from the corona virus increased by $12.2 \%$ to 5,067 people in May 2021. The figure then increased by $55.2 \%$ to 7,865 people in June 2021 . Meanwhile, the total number of deaths from the corona virus nationwide has exceeded 100,000 cases since August 4, 2021. Five provinces on the island of Java still dominate cases of death due to this virus, namely East Java, Central Java, DKI Jakarta, West Java, and DI Yogyakarta. (Lidwina, 2021)

In Jombang, the trend of new positive cases and deaths has so far decreased. As for the increase in cases, it has occurred since mid June 2021 with the top of the increase in confirmed cases and deaths, in July 15, 2021. Although the trend of cases has decreased, the citizens are asked not to be careless and remain vigilant because the Covid-19 pandemic is still ongoing. In addition to the discipline of wearing masks and diligently washing hands, people are asked to maintain a safe distance between each other and avoid crowds and reduce mobility. (Shafii, 2021)

The spread of the Corona virus (Covid-19) has clearly triggered concern for parents, especially for those who have small children. This virus doesn't care at age, both children and adults can be infected by it. Transmission of Covid-19 in children is usually caused by weak immunity or transmission from adults. The COVID-19 pandemic is affecting the care and protection of children and there are a number of vulnerabilities that should be aware of it from the authority. (Ministry of Health RI, 2021)

The Director of Family Health (Kesga) of the Ministry of Health, Erna Mulati, revealed that there was a significant increase in the number of Covid-19 transmissions in children during the last three weeks in July 2021. This figure was also the highest during the pandemic. From the official data of the Covid-19 Task Force, the number of categories of children who have been infected with Covid19 in Indonesia has reached 250,000, or around $12.8 \%$ of the total recorded cases. For ages $0-5$ years as much as $2.9 \%$ and ages 6-18 years reaching $9.9 \%$ of the total national cases. (Nua F, 2021)

In Jombang, it was recorded that at least six patients from the age of children to infants underwent intensive care. There were 6 patients who were less than 18 years old, including children aged six months, one year, five years, 10 years and 14 years. (Iskandar A, 2021)

Families need to provide education and understanding to children regarding the dangers of the virus. Starting from how to use a mask, washing hands to keeping a distance must continue to be taught and used to it. Likewise, nutritional intake and nutrition for children's health must be fulfilled. In addition, families must also protect children by getting used to not having direct contact with children when they come home from work or after leaving the house. When families or parents take care of their health, they also protect their children from transmission of Covid-19. (Nua F, 2021)

The success of implementing health protocols for children depends on how the family environment, especially parents, provides understanding and teaching related to health protocols to prevent the spread of COVID-19. Based on the results of the study, it shows that people who have a positive attitude, readiness and encouragement to change behavior apply the right health protocol. And this cannot be separated from knowledge about the application of good health protocols as well. that knowledge will increase their worried attitude at the fast spread of the virus and its impact. This attitude prompted them to take action to invite the community to make efforts to prevent and overcome the impact of the pandemic. Real knowledge and action from the public regarding health protocols will be able to help reduce the number of COVID-19 cases, so that the COVID-19 pandemic period will end quickly (Baharuddin, 2021).

\section{METHOD}

This type of research is a descriptive study that describes the level of knowledge and attitudes of parents in implementing health protocols for children during the Covid-19 pandemic. In this study, the population is parents who have children who attend Darul Falah Kindergarten Cukir Jombang. The sample in the study were 30 respondents. The sampling used is purposive sampling.

This research was conducted at Darul Falah Kindergarten, Cukir Jombang in July - September 2021.

Data collection techniques in this study is using primary data. The measuring instrument used is a closed questionnaire in the form of a google form about the knowledge and attitudes of respondents which is distributed through the school whatsapp group. The data that has been collected is processed by percentage and presented in the form of a table. 


\section{RESULTS}

Distribution of Respondents Based on Knowledge of the Implementation of the Covid-19 Health Protocol

The variable of parental knowledge in implementing health protocols for children during the COVID-19 pandemic used 30 respondents. The question category regarding knowledge of the application of health protocols during the COVID-19 pandemic is divided into 3, namely good, enough and less. The frequency distribution of parental knowledge variables in the application of health protocols during the covid-19 pandemic is shown in table 1:

Table 1 Knowlodge Frequency Distribution

\begin{tabular}{|c|c|c|}
\hline Knowledge & amount (n) & Presentage (\%) \\
\hline - good & 26 & 86,7 \\
\hline - enough & 4 & 13,3 \\
\hline - less & - & - \\
\hline Total & 30 & 100,0 \\
\hline
\end{tabular}

Source: primary data processed, 2021

Table 1 shows that most of the $86.7 \%$ ) respondents have good knowledge about the implementation of health protocols during the covid-19 pandemic.

Distribution of Respondents Based on Attitudes for implementing health protocols during the covid-19 pandemic

The variable of parents' attitudes in implementing health protocols for children during the COVID-19 pandemic is divided into 2 categories, namely positive attitudes and negative attitudes. The distribution of attitude variables is shown in table 2 as follows:

Table 2 Frequency distribution of parental attitudes in implementing health protocols for children during the Covid-19 pandemic Attitude

\begin{tabular}{ccc}
\hline Attitude & Amount (n) & Presentage (\%) \\
\hline positive & 30 & 100 \\
\hline negative & 0 & 0 \\
\hline Total & $\mathbf{3 0}$ & $\mathbf{1 0 0 , 0}$ \\
\hline
\end{tabular}

Source: primary data processed, 2021

Table 2 shows that all respondents have a positive attitude in implementing health protocols for children during the covid-19 pandemic.

\section{DISCUSSION}

Knowledge of the implementation of health protocols during covid-19 pandemic

Parents have a responsibility for the health of family members, especially children. Parents must have sufficient knowledge about health. Knowledge about health will affect behavior as a longterm outcome of health education ((Notoatmodjo,2007). In this study, the respondent's level of knowledge related to the implementation of health protocols during the covid-19 pandemic was mostly good. One of the factors that influence knowledge is information. This is as stated by Mubarok, et al (2007) received by a person plays a role in influencing one's knowledge. Information obtained from both formal and non-formal education can provide short-term knowledge, resulting in changes and increases in knowledge. We know that information about covid-19, both prevention and treatment, has been intensively disseminated by the government, health workers from electronic media such as television, radio. From the internet and mass media such as magazines, books, etc. or in the other words information about covid-19 is already accessible.

Most people easily through various sources, So they will get more the information. Mubarok, et al (2007) thought that the ease of obtaining information can help accelerate a person to acquire new knowledge. Parents can use it as a foundation for shaping behavior as azwar (2002) argues that 
information is the whole meaning that can be interpreted as a person's notification. The existence of new information about something provides a new cognitive foundation for the formation of attitudes towards it and reflected in action. In other words, parents who have knowledge related to the implementation of health protocols in the covid-19 pandemic, then people will be able to take a stand in maintaining family health, especially children to avoid covid-19.

\section{Attitude of implementing health protocols in the pandemic covid-19}

Attitude is the readiness of the self to act or react in a certain way. According to Notoatmodjo, 2007, attitude is an expression of a person's feelings that reflect his liking or dislike of an object. Attitude does not mean a behavior or action but rather a person's readiness to react to certain objects (Sukesih, et al., 2020)

Based on the results of the study obtained that the overall attitude of parents in the application of health protocols during the covid-19 pandemic in children showed a positive attitude. This is directly proportional to the knowledge of parents, most of whom have good knowledge related to the implementation of the covid-19 health protocol.

Azwar (2002) thougth that the formation of attitudes is influenced by personal experience, culture, educational institutions and religious institutions and mass media. Information conveyed through various information media and information from others will provide a cognitive foundation for attitude formation. If the messages conveyed are suggestive enough will provide the basis of the formation of parental attitudes in applying the covid-19 health protocol to children.

\section{CONCLUSIONS AND SUGGESTIONS}

Parents's knowledge who have school children in Darul Falah Cukir kindergarten in the implementation of the Covid 19 protocol is mostly good and the attitude of parents as a whole has a positive attitude towards the implementation of health protocols during the Covid-19 pandemic in children.

The advice for parents is that parents are expected to always facilitate children in implementing health protocols to prevent the spread of covid-19 such as providing masks, handsanitizers teaching to wear masks properly, washing hands, maintaining distance, etc. because children are very susceptible to various diseases. In addition, limiting children from leaving the house without a clear purpose and making activities that are fun, interesting and creative so that children do not get bored.

\section{REFFERENCES}

Azwar, S. 2002. Sikap manusia. Yogyakarta. Pustaka Pelajar : Offset.

Baharudddin. 2021. Gambaran Pengetahuan, Sikap, Dan Tindakan Penereapan Protokol Kesehatan Covid-19 Warga Di Wilayah Percontohan Program Rt Siaga Kota Surabaya. Jurnal Kesehatan Masyarakat; FKM Universitas Tadulako.

CNN Indonesia. 2020. Kilas Balik Pandemi Covid-19 Di Indonesia. https://www.cnnindonesia.com

Kemenkes RI. 2020. Panduan Pelayanan Kesehatan Balita Pada Masa Tanggap Darurat COVID-19 Bagi Petugas Kesehatan. Kemenkes RI.

Lidwina A. 2021. Kematian Covid-19 Naik Hampir 350\% Pada Juli 2021. https://databoks.katadata.co.id

Mubarok, W.I, dkk. 2007. Promosi kesehatan sebuah pengantar proses belajar mengajar dalam pendidikan. Yogyakarta: Graha Ilmu.

Notoatmodjo, S. 2007. Promosi kesehatan \& ilmu perilaku. Jakarta: Rineka Cipta

Nua F. 2021. Kemenkes : Kasus Covid-19 Pada Anak Tertinggi Di Juli 2021. https://mediaindonesia.com.

Sukesih, Usman, Budi S, Nur Adkhana Sari D. Pengetahuan Dan Sikap Mahasiswa Kesehatan Tentang Pencegahan Covid-19 Di Indonesia. J Ilmu Keperawatan dan Kebidanan. 2020;11(2):410-4.

Syafii M. 2021. Kasus Kematian Tinggi, Satgas Covid-19 Jombang: 90 Persen Pasien yang Meninggal Belum Vaksin. https://regional.kompas.com.

Iskandar A. 2021. Korona Juga sasar Anak Anak Hingga Balita. https://radarjombang.jawapos.com. 